\title{
Heavy Metal Contents in Tissues of Fishes in Andong and Imha Reservoirs
}

\author{
Myung Ja Shin, Young Mi Park, Jong Eun Lee and Eul Won Seo*
}

Department of Biological Science, Andong National University, Andong 760-749, Korea

Received July 7, 2010 /Accepted September 16, 2010

\begin{abstract}
The present study aimed to investigate the effect of heavy metal contamination in the aquatic environment on the fishes (Opsariichthys bidens, Cyprinus carpio, Hemiculter eigenmanni and Culter brevicauda) inhabiting Andong and Imha reservoirs by comparing and analyzing the heavy metal contents accumulated in their tissues. Heavy metal contents were shown to be higher in the Andong reservoir than in the Imha reservoir. Accumulated heavy metals, $\mathrm{Cr}, \mathrm{Cu}$ and $\mathrm{Pb}$, were detected in tissues and bone tissues, but Cd was also found in the kidneys. Zn content was the highest among accumulated metals, whereas $\mathrm{Cu}$ content was the lowest in all tissues from the fishes in the Andong and Imha reservoirs. However, the amount of $\mathrm{Cr}$ in the tissues showed a twofold higher level in the Andong reservoir than that in Imha reservoir. The heavy metal contents of fish inhabiting the Andong reservoir were detected to be higher than those in the Imha reservoir. We also proposed that heavy metal contamination in water and its inhabiting fish is attributed to various heavy metals derived from water and sediments in the water environment of the Andong reservoir.
\end{abstract}

Key words : Heavy metal, fishes, tissues, Andong reservoir, Imha reservoir

\section{서 론}

산업화와 자원개발에 따른 부차적인 현상 중의 하나는 환경 오염이다. 환경오염의 가능성에는 수질, 대기, 토양들에 대한 오염들을 들 수 있는데 최근에 직면하고 있는 문제 중의 하나 는 광산 활동에 의해 발생된 광미, 광폐석 등에 의한 것으로 광산폐수, 광산폐기물 등이 있다. 이러한 여러 종류의 오염 물질이 지하수, 강, 토양을 포함한 자연 생태계에 유입되어 유해물질의 양이 자정능력의 범위를 넘으면서 발생되어 환경 문제를 일으키고 있다[16]. 결국 주변 지역에 미치는 오염의 주원인은 광산을 개발 활용 시 발생되는 오염물질이 부하량을 초과하는 것이 주된 원인이다. 또한 이들이 휴·폐광된 후 광미 적치장, 폐갱도, 폐석 등에서 침출수를 발생시켜 토양 및 수계 를 통하여 이동하면서 하천, 토양 및 농작물을 오염시키고 있 으며, 식물의 생육장해는 물론 먹이연쇄를 통하여 직·간접적 으로 사람과 가축에 피해를 줄 수 있다[6,9].

경상도 지역에 식수, 농업용수 및 공업용수로서 주로 이용 되고 있으며 전력을 공급하고 있는 안동댐과 임하댐의 대형 인공호는 서로 다른 특징을 보이고 있다. 안동호의 유역내의 주요 경제 활동은 농.축산업이지만, 석탄 폐광산과 여러 개의 휴·폐광된 광산이 존재하고 있음으로 인해 폐광산의 침출수 등이 하천으로 유입됨으로써 안동호는 총인, 총질소 및 엽록 소 농도로 볼 때 중영양호에서 부영양호 사이에 있는 것으로 보고되었다[3]. 그러나 임하호 유역은 농촌의존형의 경제구조

\section{*Corresponding author}

Tel : +82-54-820-5462, Fax : +82-54-820-7705

E-mail : ewseo@andong.ac.kr
로 하천 인근주변을 중심으로 경작지가 발달되어 있으며, 폐 광된 광산이 존재하고 있으나 안동호 유역에 비해서는 매우 미비한 숫자에 지나지 않는다. 그러나 지질학적 구조로 인하 여 적갈색과 적색의 셰일과 알코스 사암 등이 호층을 이룸으 로써 점토광물을 많이 포함하고 풍화가 쉽게 일어나 탁수의 발생이 빈번하게 일어나고 있으며 잘 침강하지 않는 특징을 지니고 있다[5].

생물체 내의 중금속은 주변 환경의 중금속 농도를 반영하고 생물체 내의 총 중금속 함량은 각 조직에 분포하고 있는 중금 속의 합이라고 볼 수 있다. 또한 중금속은 모든 조직에 대해 일정한 분포를 보이지 않고 간, 신장, 아가미, 소화선 등에 선 택적으로 축적되므로 많은 양의 중금속을 축적하는 능력이 있는 조직을 중금속 오염 감시에 선별적으로 이용하면 더욱 효과적인 오염조사를 할 수 있다[14]. 더불어 광산배수가 생물 에 미치는 영향을 알아보기 위해 안동호와 임하호의 수질과 저니 내 중금속 함량을 조사한 결과 수질의 경우 $\mathrm{Cr}, \mathrm{Cd}, \mathrm{As}$ 와 저니에서는 $\mathrm{Cu}, \mathrm{Zn}, \mathrm{Pb}$ 및 $\mathrm{As}$ 가 안동호에서 높은 함량을 보였 다. 또한 안동호와 임하호에 서식하는 붕어의 중금속 함량은 임하호에 서식하는 붕어 보다 안동호에 서식하는 붕어에서 $\mathrm{Cr}, \mathrm{Cu}, \mathrm{Cd}$ 및 $\mathrm{As}$ 가 높은 함량을 보임으로써 수환경 내 유기물 을 붕어가 먹이로 섭취함으로써 붕어 체내의 중금속 함량에 영향을 준 것이라 하였다[10].

끄리(Opsariichthys bidens), 잉어(Cyprinus carpio), 치리 (Hemiculter eigenmanni) 및 백조어(Culter brevicauda)는 모두 잉어과에 속하는 어류로써 서식환경과 식성이 다른 차이점을 가지고 있다. 끄리, 잉어, 치리, 백조어는 큰 강, 호수, 저수지, 늪 등에 서식을 하지만 주로 끄리는 수질 2급수의 환경에 서식 
을 하며, 잉어, 치리 및 백조어는 주로 수질 3 급수에서 서식을 한다. 그러나 백조어는 물살이 느린 큰 강의 중, 하류에 서식하 며, 치리는 물의 표층이나 중층, 잉어는 큰 강이나 호수와 늪의 비교적 깊은 곳에 서식하고 있다. 또한 끄리와 백조어는 주로 육식성 어종으로 분류되며, 치리와 잉어는 잡식성 어종으로 분류되고 있다[8].

따라서 본 연구에서는 Kim [10]등의 보고에서 수환경 내 수질과 저니에서 중금속 함량이 높은 안동호와 이에 비해 중 금속 함량이 낮았던 임하호를 대상으로 수환경의 중금속 농도 가 어류에 미치는 영향을 알아보고자 양호에 주로 서식하는 잉어과 어류로써 개체수 구성비가 높으며, 생태적 서식 특성 및 식성이 서로 다른 끄리(Opsariichthys bidens), 잉어(Cyprinus carpio), 치리(Hemiculter eigenmanni) 및 백조어(Culter brevicau$d a$ )를 이용하여 부위별(아가미, 신장, 뽸, 비늘, 근육) 중금속 $(\mathrm{Cd}, \mathrm{Cr}, \mathrm{Cu}, \mathrm{Pb}, \mathrm{Zn})$ 함량을 측정하여 비교 분석하였다.

\section{재료 및 방법}

\section{실험 어류 및 시료 채취}

실험에 사용된 어류는 안동호 2 개의 지점과 임하호 2 개의 지점을 선정하여 2005년 3회(5월, 7월, 9월)와 2006년 3회(8월, 9월, 10 월)에 걸쳐 2 년간 채집하였다(Fig. 1). 채집은 3 중자망 (망목 $10 \times 10 \mathrm{~mm}, 25 \times 25 \mathrm{~mm}$ )을 사용하여 설치 48 시간 정치 후 수거하였다. 채집된 어류 중 끄리(O. bidens), 잉어(C. carpio), 치리(H. eigenmanni), 백조어(C. brevicauda)는 현장에서 Kim [7], Kim과 Park [8]을 참고하여 동정하였다. 동정 후, 즉 시 실험실로 운반하여 약 2년생의 끄리(전장 $131.51 \pm 11.57$ $\mathrm{mm}$, 체중 $68.31 \pm 17.94 \mathrm{~g}$ )와 잉어(전장 $169.59 \pm 9.65 \mathrm{~mm}$, 체중 $103.05 \pm 9.83 \mathrm{~g}$ ), 약 3 년생의 치리(전장 $141.27 \pm 10.12 \mathrm{~mm}$, 체중 $37.84 \pm 4.63 \mathrm{~g}$ )와 백조어(전장 $227.28 \pm 24.09 \mathrm{~mm}$, 체중 89.39 $\pm 23.38 \mathrm{~g}$ ) 각각 개체를 10 마리씩을 실험에 사용하였다.

\section{분석 방법}

채집된 어류의 각 조직 내 중금속 함량을 분석하기 위해 채집한 어류는 개체별로 해부를 통하여 비늘, 아가미, 근육, 빼, 신장 조직을 적출하여 증류수로 세척한 후 초음파 세척기 (5210, Branson, USA)로 최대한 조직에 붙어 있는 이물질을 제거하였다. 이물질이 제거된 시료는 $-80^{\circ} \mathrm{C}$ 에서 동결시킨 후 냉동건조하여 수분을 제거한 후 $0.5 \mathrm{~g}$ 을 취하여 혼합산 $\left(\mathrm{HNO}_{3}: \mathrm{H}_{2} \mathrm{O}_{2}=7: 1, \mathrm{Merck}\right)$ 을 초음파용해장치용 용기(Teflon vessel) 안에 넣었다. 부위별 조직과 혼합산이 혼합된 용기는 초음파용해장치(Microwave digestion system, Prolabo Microdigestion 3, France)을 이용하여 $200^{\circ} \mathrm{C}$ 에서 30 분간 분해 하였다. 분해 된 시료는 $50 \mathrm{ml}$ 정량병에 희석하여 구리 $(\mathrm{Cu})$, 카드뮴 $(\mathrm{Cd})$, 크롬 $\left(\mathrm{Cr}^{6+}\right)$ 및 아연 $(\mathrm{Zn})$ 을 유도결합 플라즈마 방

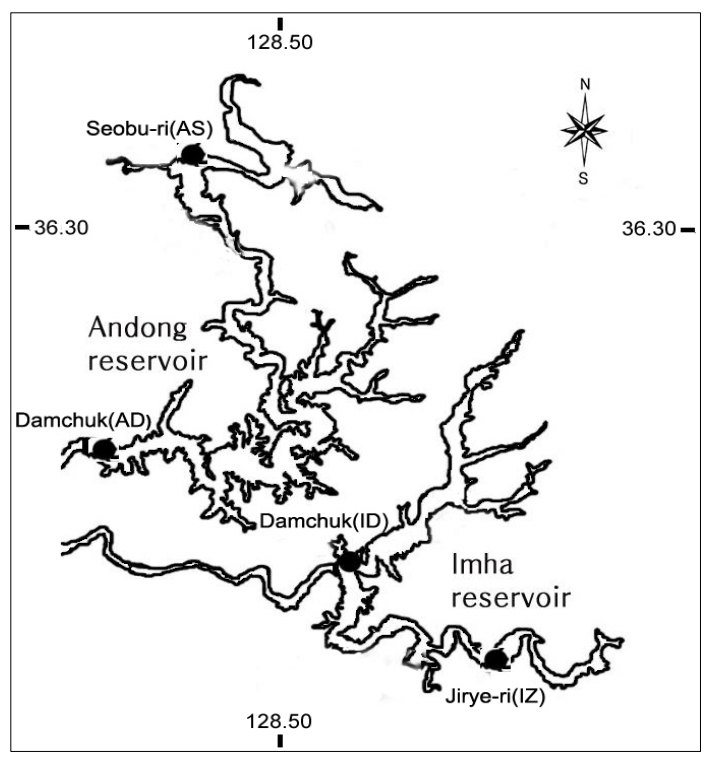

Fig. 1. Map showing the sampling sites in Andong and Imha reservoirs.

출분광기(Flame Modula S, Spectro, Germany)에서 분석하였 다. 또한 납 $(\mathrm{Pb})$ 의 분석은 원자흡수분광계(SpectrAA-220FS, Varian, Australia)를 이용하여 측정하였다.

\section{통계처리}

각 실험에서 얻어진 자료에 대하여 통계 프로그램 패키지 (SPSS Inc., ver 12.0K, USA)를 이용하여 Levene의 등분산 검 정과 평균의 동일성에 대한 T-검정을 통하여 각 실험 사이에 $\mathrm{p}<0.05$ 를 유의차가 있는 것으로 간주하고 유의적인 차이를 조 사하였다.

\section{결과 및 고찰}

생태계로 유입되는 중금속의 인위적인 배출원은 광산과 제 련소, 공장, 자동차, 농업용 살충제, 쓰레기 등으로 구분할 수 있는데, 최근 국내에서는 폐광지와 소각로의 증가로 주변 토 양에서의 중금속 농도가 매우 높게 나타나 사회적으로 문제가 되고 있다[2]. 또한 폐광산에서 발생된 폐광산 주변 토양, 폐석 등은 광산 주변에 부적절하게 방치되었다가 강우 시 유출되어 주변토양과 하천 등을 오염시키며, 이러한 중금속은 먹이사슬 을 통해 결국 인체에 유해한 영향을 끼치게 된다[13]. 더불어 각종 미량 금속과 유기 금속 그리고 유기화학물질 등을 포함 한 다양한 오염 물질은 수생 환경에 서식하는 생물들의 생리 활동과 성장, 생식에 위해를 가함으로써 개체군이 감소하고 군집구조가 변화하는 등 수생 생태계를 손상시키는 주요 원인 의 하나로 등장하고 있다. 그러므로 이에 대한 연구자들의 관 심은 지속적으로 증가하는 추세에 있고 오염물질의 생물학적 영향을 정량하는 다양한 생물 검정 기술이 개발되어 수생 환 
경오염의 생물학적 모니터링과 환경 위해도 평가에 활용되고 있다[12]. 따라서 본 연구에서는 안동호와 임하호의 서식어종 으로 개체수 구성비가 높은 잉어과 어류로써 끄리(O. bidens), 잉어(C. carpio), 치리(H. eigenmanni), 백조어(C. brevicauda)의 부위에 따른 중금속 함량을 측정하여 서식 어종간의 중금속 축적량을 비교 분석하고자 하였다.

\section{안동·임하호 수종 어류 조직 내 $\mathrm{Cr}$ 의 함량 비교}

안동호 어류 조직 내 $\mathrm{Cr}$ 의 평균 함량은 $0.495 \pm 0.120 \mu \mathrm{g} / \mathrm{g}$ 로 임하호 어류 조직 내 평균 함량인 $0.266 \pm 0.066 \mathrm{\mu g} / \mathrm{g}$ 보다 높았 으며, 안동호에 서식하는 어류의 모든 조직에서 높은 함량을 나타냈다. 또한 어류 조직 중 가장 높은 함량은 안동호 치리 빼 조직으로 $1.138 \pm 0.048 \mathrm{\mu g} / \mathrm{g}$ 이며, 임하호 잉어 아가미 조직 이 $0.012 \pm 0.005 \mu \mathrm{g} / \mathrm{g}$ 으로 가장 낮은 함량을 나타내어 어류와 조직에 따라 함량 차이가 큰 것으로 나타났다(Fig. 2). 이러한 결과로 보아 $\mathrm{Cr}$ 의 함량은 빼와 비늘 조직에서 높았고, 아가미 조직에서 낮은 것으로 나타나 어류가 수환경 내의 먹이 섭취 과정에서 $\mathrm{Cr}$ 이 체내에 축적되어 빼와 비늘 조직에서 높은 함 량을 나타낸 것으로 생각된다. 또한 Kim 등[10]은 안동호와 임하호에 서식하는 붕어의 조직 내 $\mathrm{Cr}$ 의 함량도 뼈 조직에서

\section{A}

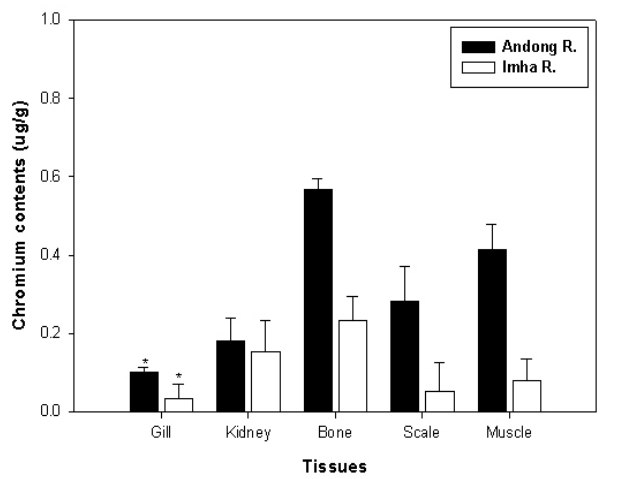

C

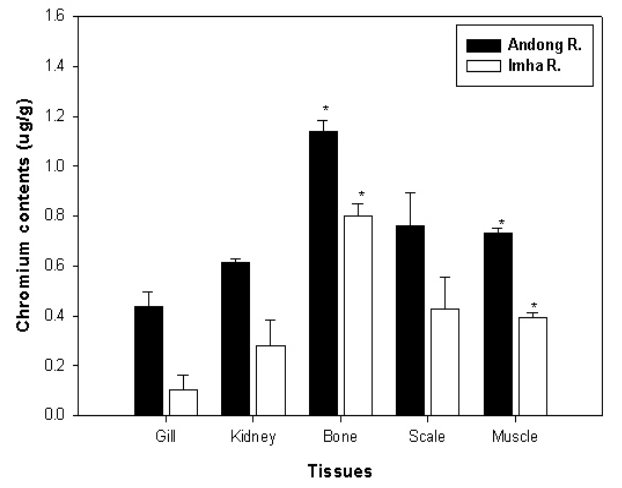

높은 함량을 보이며 아가미 조직에서 낮은 함량을 나타내어 유사한 결과를 나타냈다.

\section{$\mathrm{Cd}$ 의 함량 비교}

안동호 어류 조직 내 $\mathrm{Cd}$ 의 평균 함량은 $0.311 \pm 0.084 \mathrm{\mu g} / \mathrm{g}$ 으 로 임하호 어류 조직 내 평균 함량인 $0.161 \pm 0.072 \mu \mathrm{g} / \mathrm{g}$ 보다 높았으나 함량의 차이는 크지 않았다. 어류 조직 중 가장 높은 함량은 안동호에 서식하는 백조어 신장 조직으로 $1.445 \pm 0.168$ $\mu \mathrm{g} / \mathrm{g}$ 이며, 임하호의 백조어 근육 조직이 $0.013 \pm 0.003 \mu \mathrm{g} / \mathrm{g}$ 으 로 가장 낮은 함량을 나타내어 어류 조직 내 함량 차이가 큰 것으로 나타났다. 또한 아가미 조직을 제외하고는 안동호에 서식하는 어류의 조직에서 높은 함량을 나타냈다(Fig. 3). Yayoi 등[18]은 환경 수중에 $\mathrm{Cd}$ 이 존재할 경우에 어류 체내에 서 축적되는 중금속의 양은 신장에 가장 많고, 다음은 아가미 와 간, 췌장이라고 하였는데, 본 연구에서도 $\mathrm{Cd}$ 의 함량은 어류 의 조직 중 신장과 아가미 조직에서 높은 함량을 나타내어 Yayoi 등[18]의 보고와 유사한 결과를 나타냈다.

\section{$\mathrm{Pb}$ 의 함량 비교}

안동호에 서식하는 어류 조직 내 $\mathrm{Pb}$ 의 평균함량은 $0.305 \pm$

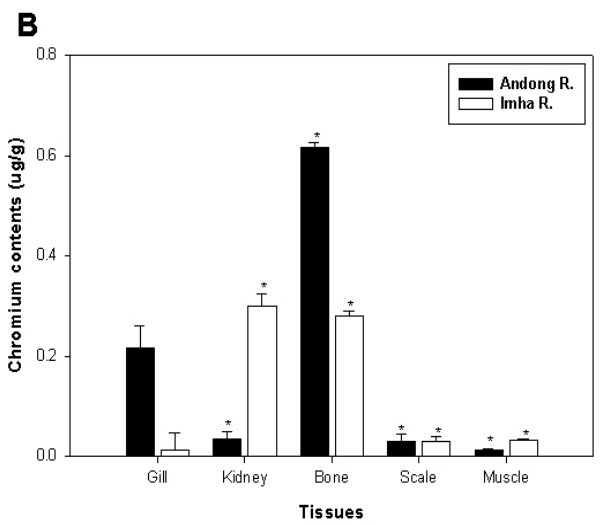

D

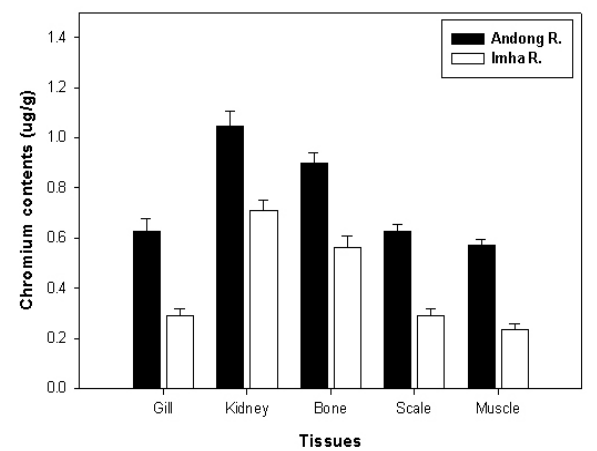

Fig. 2. Cr contents of O. bidens (A), C. carpio (B), H. eigenmanni (C) and C. brevicauda (D) in Andong and Imha reservoirs. Cr was higher in Andong reservoir than Imha reservoir. In tissues, the contents of bone was shown to be highest. In fishes, the contents of C. brevicauda (D) was shown to be highest. The bar shows the mean standard deviation $(\mathrm{n}=3)$. $p<0.05$ as compared to Andong and Imha reservoirs and tissues. 
A

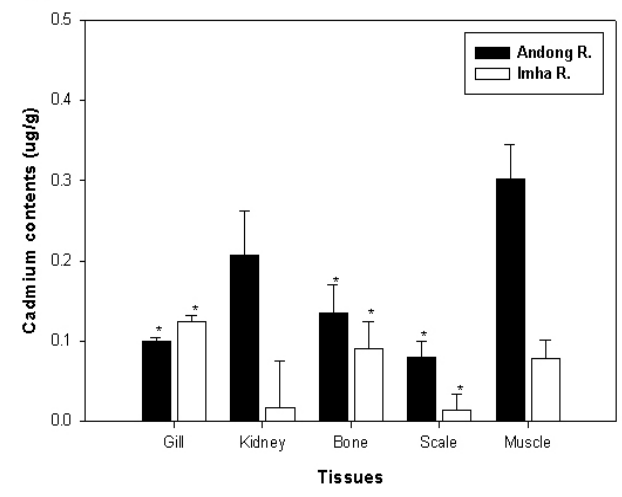

C

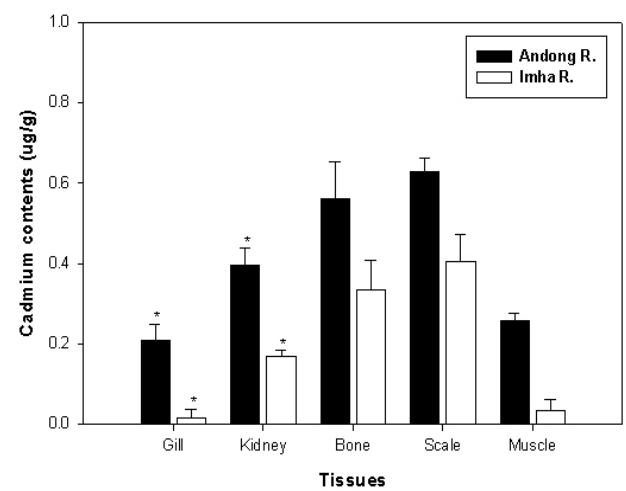

B

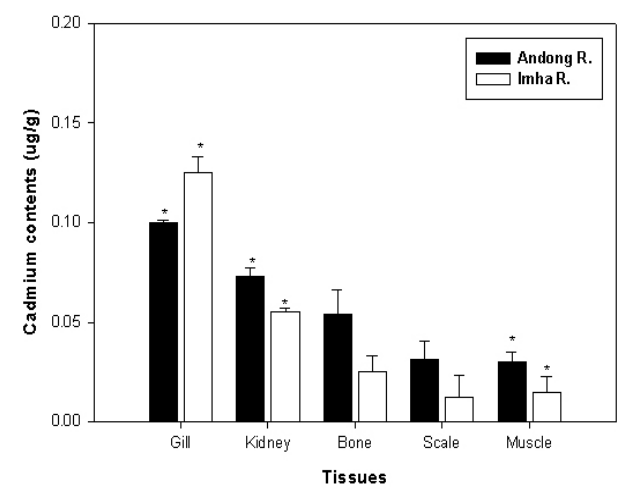

D

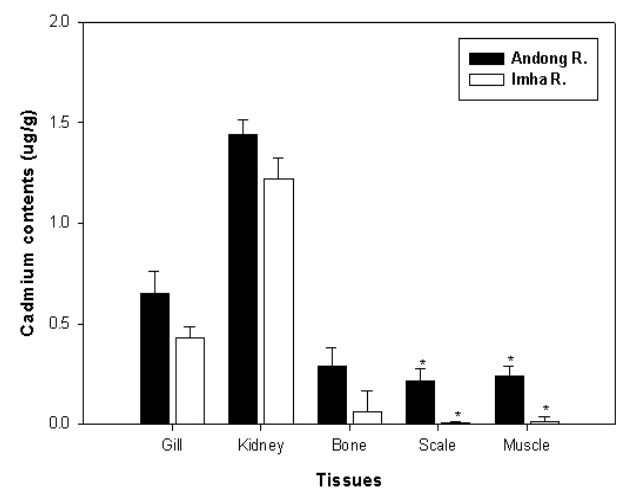

Fig. 3. Cd contents of O. bidens (A), C. carpio (B), H. eigenmanni (C) and C. brevicauda (D) in Andong and Imha reservoirs. Cd was higher in Andong reservoir than Imha reservoir. In tissues, the contents of kidney and gill showed high. In fishes, the contents of H. eigenmanni (C) and C. brevicauda (D) showed high. The bar shows the mean standard deviation $(\mathrm{n}=3)$. $p<0.05$ as compared to Andong and Imha reservoirs and tissues.

$0.033 \mu \mathrm{g} / \mathrm{g}$ 으로 임하호에 서식하는 어류 조직 내 평균함량인 $0.228 \pm 0.031 \mathrm{\mu g} / \mathrm{g}$ 보다 높았으나 함량의 차이는 크지 않았다. 어류 조직 중 가장 높은 함량은 안동호 백조어 빼 조직으로 $0.961 \pm 0.179 \mu \mathrm{g} / \mathrm{g}$ 이며, 가장 낮은 함량은 임하호 끄리 신장 조직으로 $0.018 \pm 0.006 \mu \mathrm{g} / \mathrm{g}$ 로 나타나 어류와 조직 간에 함량 차이가 큰 것으로 나타났다. 또한 신장 조직을 제외하고는 안 동호에 서식하는 어류의 조직에서 높은 함량을 보였다(Fig. 4). 특히 수중에 함유된 $\mathrm{Pb}$ 은 동물의 소화기, 호흡기, 피부를 통해 주로 흡수하게 되며, 흡입 및 섭취에 의해 동물의 체내에 흡수된 $\mathrm{Pb}$ 은 혈액을 통해 배설되나 나머지는 간, 신장, 근육, 빼 등에 저류되어 축적을 일으키게 된다[1,11]. 본 연구의 결과 $\mathrm{Pb}$ 의 함량은 양호의 빼와 아가미 조직에서 높은 함량을 나타 내어 호흡기인 아가미를 통해 주로 흡수된 것으로 생각되며, 흡수된 $\mathrm{Pb}$ 는 빼에 저류되어 축적된 것으로 사료된다.

\section{$\mathrm{Cu}, \mathrm{Zn}$ 의 함량 비교}

안동호에 서식하는 어류 조직 내 $\mathrm{Cu}$ 의 평균함량은 $0.176 \pm$ $0.040 \mathrm{\mu g} / \mathrm{g}$ 으로 임하호에 서식하는 어류 조직 내 평균함량인 $0.106 \pm 0.037 \mu \mathrm{g} / \mathrm{g}$ 보다 높았으나 함량의 차이는 크지 않았다.
그러나 어류 조직 중 가장 높은 함량은 임하호 치리 아가미 조직으로 $0.485 \pm 0.105 \mu \mathrm{g} / \mathrm{g}$ 이며, 가장 낮은 함량은 임하호 끄 리 근육 조직이 $0.005 \pm 0.001 \mu \mathrm{g} / \mathrm{g}$ 으로 임하호에 서식하는 어 류 조직 내 함량의 편차가 큰 것으로 나타났다. 또한 안동호에 서식하는 어류 조직 내 함량은 편차가 크지 않았으며, 아가미 와 신장 조직을 제외하고 안동호의 어류 조직에서 높은 함량 을 나타냈다(Fig. 5). 안동호 어류 조직 내 $\mathrm{Zn}$ 의 평균함량은 $36.218 \pm 6.183 \mu \mathrm{g} / \mathrm{g}$ 으로 임하호 어류 조직 내 평균함량인 $29.793 \pm 5.014 \mu \mathrm{g} / \mathrm{g}$ 보다 높았으나 함량 차이는 크지 않았다. 어류 조직 중 가장 높은 함량은 안동호 잉어 아가미 조직으로 $146.625 \pm 8.375 \mu \mathrm{g} / \mathrm{g}$ 이며, 가장 낮은 함량은 임하호 잉어 근육 조직으로 $8.403 \pm 0.018 \mu \mathrm{g} / \mathrm{g}$ 으로 나타났다. 따라서 안동호와 임하호에 서식하는 어류와 조직 간의 함량 차이가 컸으며, 안 동호에 서식하는 어류의 조직 내 함량이 모두 높았다(Fig. 6). 본 연구의 결과 $\mathrm{Cu}$ 와 $\mathrm{Zn}$ 의 함량은 빼와 아가미 조직에서 높은 함량을 보이고 근육과 비늘 조직에서 낮은 함량을 나타냈다. 이는 Moore와 Ramlamoorthy [15]의 보고에서 $\mathrm{Cu}$ 와 $\mathrm{Zn}$ 는 근 육보다 간장, 비장 및 아가미에서 높은 축적량을 나타내는 것 과 유사한 결과를 나타냈다. 또한 $\mathrm{Zn}$ 의 함량은 안동호와 임하 
A

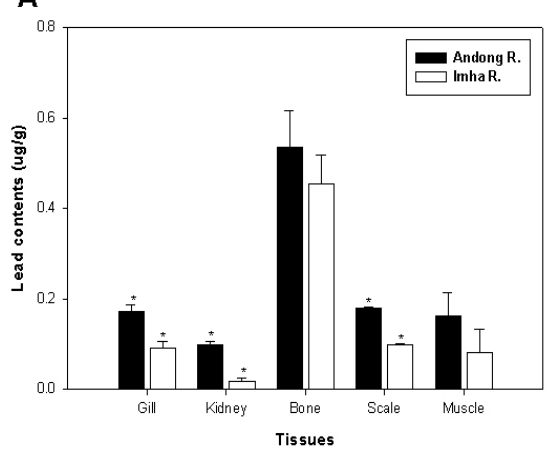

C

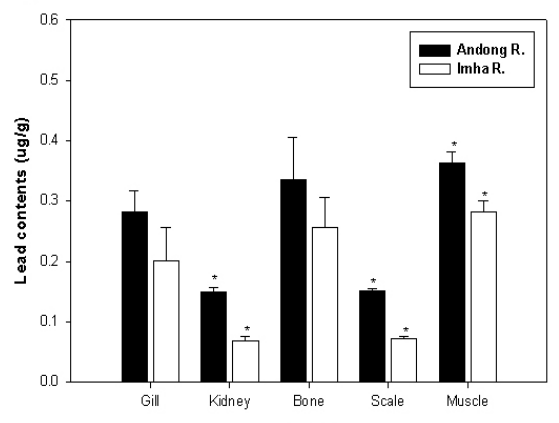

B

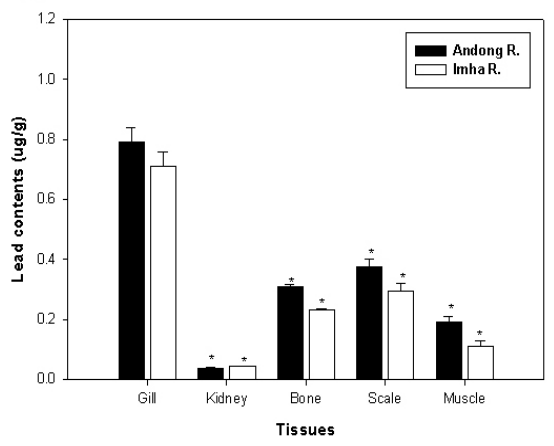

D

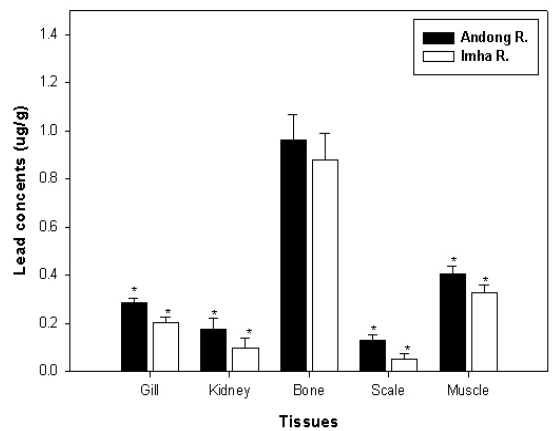

Fig. 4. $\mathrm{Pb}$ contents of O. bidens (A), C. carpio (B), H. eigenmanni (C) and C. brevicauda (D) in Andong and Imha reservoirs. Pb was shown higher in the Andong reservoir. In tissues, the contents of bone and gill showed high, and the difference in the contents between Andong reservoir and Imha reservoir was shown to be lower. In fishes, the contents of $C$. carpio (B) and C. brevicauda (D) showed high. The bar shows the mean standard deviation $(\mathrm{n}=3) . p<0.05$ as compared to Andong and Imha reservoirs and tissues.

A

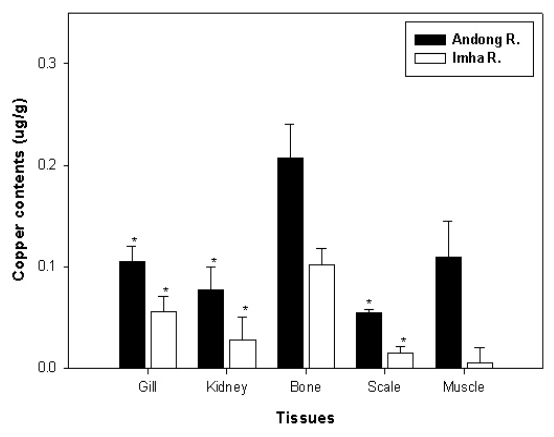

C

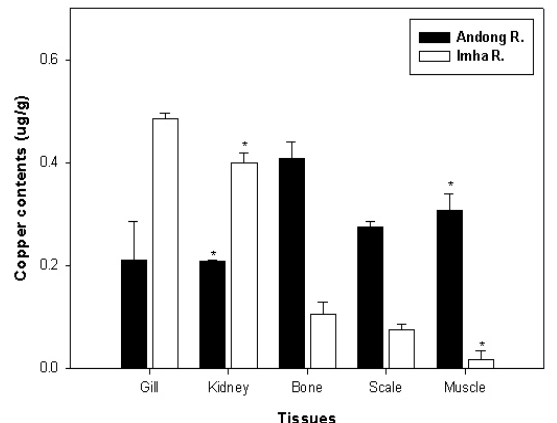

B

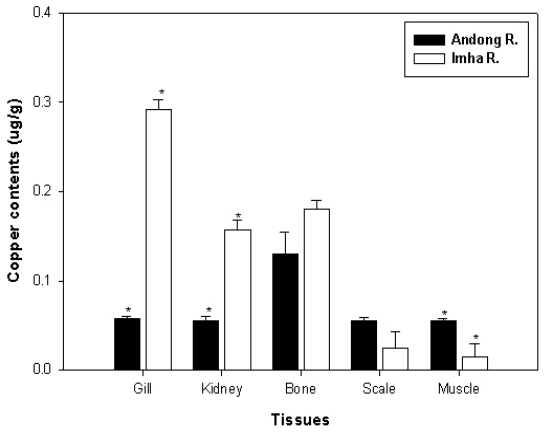

D

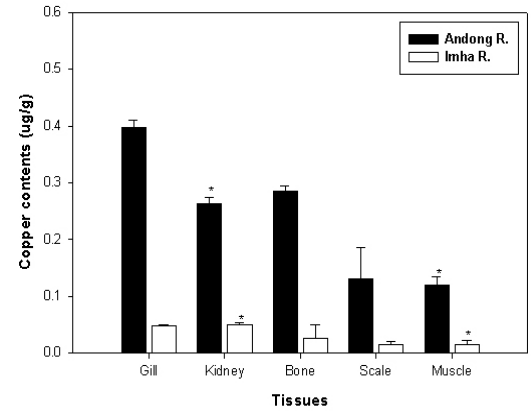

Fig. 5. Cu contents of O. bidens (A), C. carpio (B), H. eigenmanni (C) and C. brevicauda (D) in Andong and Imha reservoirs. Cu was higher in Andong reservoir than Imha reservoir. In tissues, the contents of bone and gill showed high. In fishes, the contents of H. eigenmanni $(\mathrm{C})$ was shown to be highest. The bar shows the mean standard deviation $(\mathrm{n}=3)$. $p<0.05$ as compared to Andong and Imha reservoirs and tissues. 
A

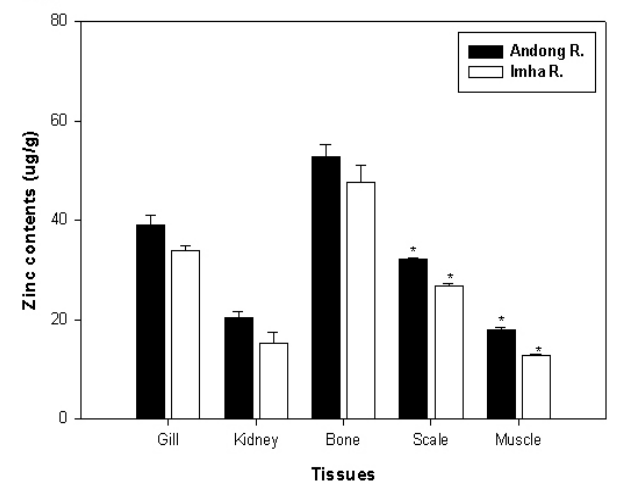

C

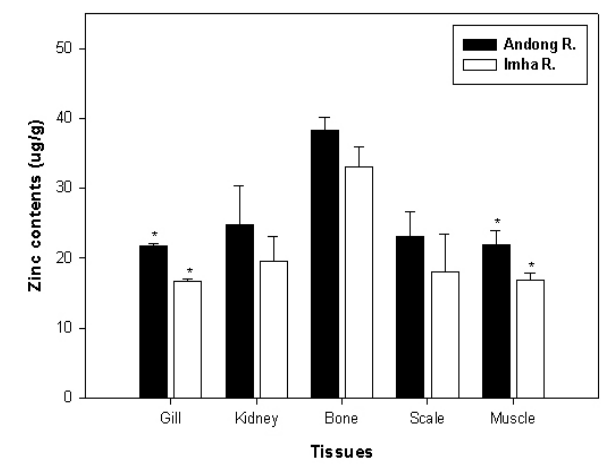

B

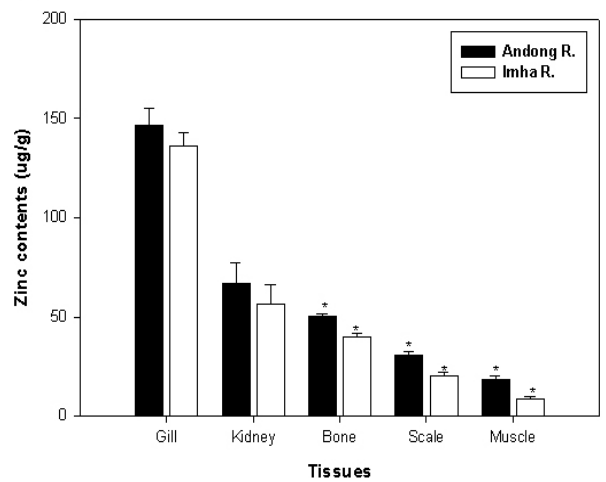

D

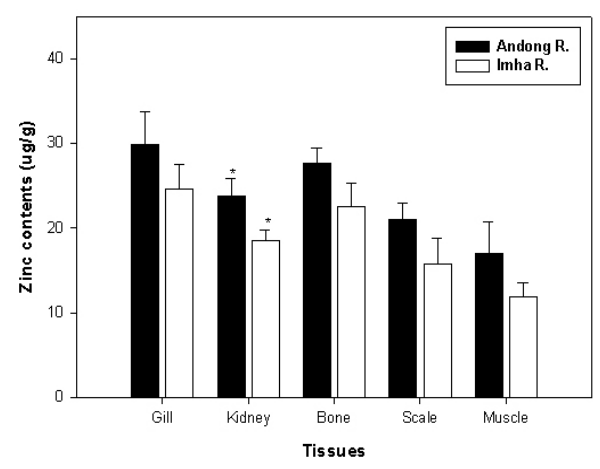

Fig. 6. Zn contents of O. bidens (A), C. carpio (B), H. eigenmanni (C) and C. brevicauda (D) in Andong and Imha reservoirs. In tissues, the contents of gill and bone was shown to be highest, and the difference in the contents between Andong reservoir and Imha reservoir was shown to be lower. In fishes, the contents of C. carpio (B) was shown to be highest. The bar shows the mean standard deviation (n=3). $p<0.05$ as compared to Andong and Imha reservoirs and tissues.

호의 수질과 저니에서 다른 중금속에 비하여 높은 함량을 나 타냈으며[10], 안동호와 임하호에 서식하는 어류에서 모두 높 은 함량을 나타냈다. 이는 안동호와 임하호의 수질과 저니에 서 $\mathrm{Zn}$ 이 높은 함량을 보인 것으로 보아 수환경의 수질과 저니 에 포함된 유기물을 어류가 먹이로 섭취함으로써 어류에서 높은 함량을 보인 것으로 생각된다.

본 연구의 결과 안동호에 서식하는 어류가 임하호에 서식하 는 어류보다 중금속의 함량이 높았으며, 빼와 아가미 조직에 서 중금속 함량이 높고 근육 조직에서 낮았다. 또한 $\mathrm{Zn}$ 은 아가 미 조직에서 가장 높은 함량을 보이고 근육 조직에서 가장 낮은 함량을 나타내어 Hwang 등[4]의 어류의 부위별 중금속 함량이 $\mathrm{Pb}, \mathrm{Cd}$ 및 $\mathrm{Cu}$ 의 경우 내장에서 가장 높고 아가미, 골 격, 근육의 순으로 감소하며 $\mathrm{Zn}$ 은 아가미에서 최고함량을 보 이고 골격, 내장, 근육의 순으로 감소한다는 것과 유사한 결과 를 나타냈다. 또한 안동호에 서식하는 어류에서 임하호에 서 식하는 어류보다 중금속 함량이 높았으나 이는 미국의 식품에 대한 허용기준치 보다 낮은 함량을 보였다[17]. 또한 우리나라 에서 서식하고 있는 어패류에 함유된 중금속 함량과 비교해 보면 유해수준이하로 나타나 안동호와 임하호에 서식하고 있 는 어류의 중금속 오염은 유해수준 이하일 것으로 사료된다.
그러나 어류 중의 각 중금속 함량의 차이는 시료의 채취시기 및 오염원에서 방출되는 중금속량의 변화 또는 수중 생태계 내에서의 생물학적 활성도 변화 등의 차이에 기인함으로 정확 한 판단을 위해서는 같은 시기, 같은 장소의 중금속 함량 조사 가 계속적으로 연구가 이루어져야 할 것으로 생각된다.

\section{References}

1. Black, J. J. and P. C. Bauman. 1991. Carcinogens and cancers in freshwater fishes. Environ. Helth Perspect 90, 27-33.

2. Han, S. H., J. O. Hyun, K. J. Lee, and D. H. Cho. 1998. Accumulation of heavy metals $(\mathrm{Cd}, \mathrm{Cu}, \mathrm{Zn}$, and $\mathrm{Pb})$ in five tree species in relation to contamination of soil near two closed zinc-mining sites. J. Korean For. Soc. 87, 466-474.

3. Heo, W. M., S. Y. Kwon, B. C. Kim, and J. H. Park, 2000. Long-term variation of water quality in lake Andong. Korean J. Limnol. 33, 260-266.

4. Hwang, I. D., S. K. No, S. Y. Gi, J. H. Lee, and N. S. Kim. 1989. A study on the heavy metal contents in fish and sediments of the Mankyung river. Korean J. Env. Helth Soc. 15, 33-49.

5. Hwang, S. K. and G. Y. Jeong. 2006. Geology in drainage field of the Imha dam and origins of high turbid water in 
the Imha lake, Andong. Econ. Environ. Geol. 39, 771-786.

6. Jung, G. B., W. I. Kim, K. H. Moon, and I. S. Ryu. 2000a. Extraction methods and availability for heavy metal in paddy soils near abandoned mining areas. J. Korean Soc. Agri. Environ. 19, 314-318.

7. Kim, I. S. 1997. Illustrated encyclopedia of fauna and flora of Korea. Freshwater Fishes. Vol. 37, Ministry of Education.

8. Kim, I. S. and J. Y. Park. 2002. Freshwater fishes of Korea. Kyohak Press.

9. Kim, H. J., J. E. Yang, J. Y. Lee, and S. H. Jun. 2005. A study on chemical speciations and leaching potential of heavy metals in polluted wastes soils. Korean Soc. Soil Ground Water Environ. 10, 1-9.

10. Kim, J. S., M. J. Shin, J. E. Lee, and E. W. Seo. 2009. Heavy metal contents in tissues of Carassius auratus in Andong and Imha reservoir. J. Life Sci. 19, 1562-1567.

11. Kimura, L., M. Yamashita, N. Kinae, H. Kumai, and G. Nakamura, 1990. The croaker (Nibea mitsukurii) and the sea catfish (Plotosus anguillaris): Useful biomarkers of coastal pollution, pp. 73-84, In Lewis Publisher (ed.), In Biomarkers of Environmental Contamination. Florida.

12. Lee, J. S., K. T. Lee, D. H. Kim, J. H. Kim, and K. N. Han.
2004. Acute toxicity of dissolved inorganic metals, organotins and polycyclic aromatic hydrocarbons to Puffer fish, Takifugu obscurus. J. Environ. Toxicol. 19, 141-151.

13. Lee, J. H., K. C. Nam, and K. S. Park. 2006. Soil washing of abandoned mine soils contaminated by heavy metals. J. Korean Soc. Water Quality 22, 871-878.

14. Mason, A. Z. and K. Simkiss. 1993. Interactions between metals and their distribution in tissues of Littorina littorea (L.) collected from clean and polluted sites. J. Mar. Biol. Ass. U. K. 63, 661-672.

15. Moore, J. W. and S. Ramlamoorthy. 1984. Heavy metals in sediments, water and biota in the Illnosis river. pp. 44-45, 85-88, 109-115, 190-198. Springe Verlag Inc., New York.

16. Sengupta, M. 1993. Environmental impacts of minc drainage on streams of United States. Environ. Geol. Water Science 11, 141-152.

17. U.S. Food and Drug Adminisration. 1998. Industry activities staff booklet. Action levels for poisonous or deleterious substances in human food and animal feed.

18. Yayoi, K., J. Koyama, and H. Ozaki. 1986. Heavy metal levels in tissues of fish exposed to cadmium. Bull. Japan Soc. Sci. Fish 52, 2055-2059.

\section{초록 : 안동·임하호에 서식하는 수종 어류의 조직 내 중금속 함량}

신명자 · 박영미· 이종은 · 서을원*

(안동대학교 자연과학대학 생명과학과)

안동호와 임하호에 서식하는 끄리(O. bidens), 잉어(C. carpio), 치리(H. eigenmanni), 백조어(C. brevicauda)의 부위 에 따른 중금속 축적량을 비교하여 수환경 내 중금속이 어류에 미치는 영향을 알아보고자 하였다. 안동호와 임하 호에 서식하는 어류의 중금속 함량은 안동호에 서식하는 어류에서 높은 함량을 보였으며, 중금속에 따라 함량의 차이도 컸다. 안동호와 임하호에 서식하는 어류에서 $\mathrm{Cr}, \mathrm{Cu}, \mathrm{Zn}$ 및 $\mathrm{Pb}$ 은 빼 조직에서 높은 함량을 보였고, $\mathrm{Cd}$ 는 신장 조직에서 높은 함량을 보였다. 부위별 중금속함량은 $\mathrm{Pb}$ 와 $\mathrm{Zn}$ 을 제외한 전 중금속에서 높은 차이를 보였으 며, 중금속별로는 $\mathrm{Zn}$ 이 가장 많았고 $\mathrm{Cd}$ 가 가장 낮았다. 또한 $\mathrm{Cr}$ 은 안동호의 어류에서 임하호 보다 2배의 높은 함량의 차이를 보였다. 본 연구의 결과 안동호에 서식하는 어류가 임하호에 서식하는 어류 보다 중금속 함량이 높았으며, 이는 안동호의 수질과 저니에서 중금속 함량이 높은 것으로 보아 수환경의 수질과 저니에 포함된 유기 물을 어류가 먹이로 섭취함으로써 어류에서도 높은 함량을 보인 것으로 생각된다. 